much wider circle than those who pursue birds with dogs and guns.J. A. A.

\title{
Report of the Chief of the Bureau of Biological Survey for $1910 .^{1}-$
}

The report of the Chief of the Biological Survey, Mr. H. W. Henshaw, on the work of the Survey contains the usual summary of its activities for the fiscal year ended June 30, 1910. As is well known to readers of 'The Auk,' the resignation of Dr. C. Hart Merriam, for so many years the efficient director of this important Bureau, became effective June 1, 1910, and the Assistant Chief, Mr. H. W. Henshaw was promoted to the vacancy, with Dr. T. S. Palmer as Assistant Chief, Dr. Merriam still retaining an official connection with the Survey under the title of Consulting Biologist. The present report therefore deals mainly with the period preceding the change in administration.

In a document so condensed, and dealing with so many subjects of general interest, reference can here be made only to those more especially relating to ornithology. Investigations of the economic relations of birds and mammals to agriculture, of the geographic distribution of animals and plants with reference to the determination of the life and crop belts of the country, the supervision of matters relating to game preservation and protection, and the importation of foreign birds and animals, are the prescribed functions of the Survey under acts of Congress. Field work was conducted during the year in twelve different States, in continuation of that of previous years. The biological survey of Colorado and New Mexico is now practically completed and the final reports thereon are nearly ready for publication. It is stated that satisfactory progress has been made in digesting and putting into shape for easy reference the accumulated mass of information on mammals and birds, including a great amount of data on the migration and distribution of North American birds. Rapid advance has also been made in mapping the distribution of both birds and mammals. A revised edition of a general zone map of the United States is also in preparation.

Under the head of National Bird Reservations, which number 51, divided into six districts, it is said: "Experiments in marking birds with bands to determine the course of migration were initiated on the Stump Lake (N. Dak.) and Klamath Lake (Oreg.) reservations, and investigations to determine the homing instinct and the power of birds to find their way back to the breeding grounds, begun by Prof. J. B. Watson in 1907 on the Tortugas (Fla.) reservation, under the direction of the Carnegie Institution, were continued in the spring of 1910."

Game protection, illegal traffic in game, coöperation in game protection with State authorities, the supervision of the importation of foreign birds and animals, investigation of the food habits of ducks, the relation of birds

\footnotetext{
1 Reprinted from Annual Reports of the Department of Agriculture, 1910. 8vo, pp. 19. Washington, Government Printing Office, 1910.
} 
to insect pests and the fruit industry, are among the numerous subjects treated in the Report, but perhaps of even greater importance are the investigation of ground squirrels and wood rats in their relation to the dissemination of the spotted fever and the bubonic plague, and of means to reduce their number, and, where necessary, to effect their extermination. The scope and efficiency of the work of the Survey is thus extended year by year to meet new emergencies and conditions; its work along economic lines is thus of the highest importance to the general welfare, in addition to its biologic phases.- J. A. A.

\section{Jacobs on the Purple Martin and Houses for its Summer Home.-}

Mr. J. Warren Jacobs contributes further welcome information ${ }^{1}$ regarding his success in supplying houses for the summer homes of the Purple Martin. This brochure of 38 pages contains a list of persons who have put up his martin houses, with many: ports from correspondents concerning the success that has attended their use. These reports are followed by several pages "On Snakes as Bird Destroyers, and their Power to 'Charm.", From the statements here made it is evident that snakes are quite destructive to not only the eggs and young of birds that nest on the ground, but also to those nesting in bushes and trees, and that even Martins nesting in bird houses are not wholly exempt from their attacks.- J. A. A.

'How to Attract and Protect Wild Birds.'- This second English edition of Hiesemann's well known work ${ }^{2}$ presents many new features and shows that there is a large demand $f \mathrm{r}$ the English version of this very useful and excellent manual of how to at act and how to promote the increase of wild birds, as well as how to prote t them from natural enemies, based on the well-known devices and experiments made during many years of close study of the subject by Baron von Berlepsch on his estate at Seebach, Germany. The legal aspect of bird protection is not treated; protection here means the provision of nesting-places for birds that breed not only in holes in trees and in sheltered niches, but also for those that breed in the open, as in fields and marshes, and in thickets and woods. Protection, in other words, means the preservation, so far as possible, of natural conditions and haunts, as well as the erection of artificial nesting-sites. A chapter is devoted to the feeding of birds in winter, and the various methods employed are illustrated as well as described.

The author refers to the principle of utilitarianism that is now so widespread among all classes of society, but has the courage to say: "We do

\footnotetext{
${ }^{1}$ Second Supplement to Gleanings No. 5. The Purple Martin (Progne subis subis) and Houses for its Summer Home. By J. Warren Jacobs. Waynesburg. Pa. Issued November 1, 1910. 8vo, pp. 57-94, with halftone illustrations.

${ }^{2}$ How to | Attract and Prot ct | Wild Birds | By | Martin Hiesemann | Translated by | Emma S. Buchheim ! With an Introduction by | Her Grace the Duchess of Bedford | Second edition with many revisions/With many illustrations London | Witherby \& Co. 326 High Holborn | 1911. 8vo, pp. 100, 40 text figures. 1s. 6d. net. Can also be ordered of the National Association of Audubon Societies, 1974 Broadway, New York City. (Note the change of address.)
} 


\section{$2 \mathrm{BHL}$ Biodiversity Heritage Library}

1911. "Report of the Chief of the Bureau of Biological Survey for 1910." The Auk 28, 280-281. https://doi.org/10.2307/4071474.

View This Item Online: https://www.biodiversitylibrary.org/item/54988

DOI: https://doi.org/10.2307/4071474

Permalink: https://www.biodiversitylibrary.org/partpdf/87453

\section{Holding Institution}

Smithsonian Libraries

\section{Sponsored by}

Smithsonian

\section{Copyright \& Reuse}

Copyright Status: Public domain. The BHL considers that this work is no longer under copyright protection.

This document was created from content at the Biodiversity Heritage Library, the world's largest open access digital library for biodiversity literature and archives. Visit BHL at https://www.biodiversitylibrary.org. 